\title{
Inhibition of lymphocyte stimulation by bovine uterine proteins
}

\author{
G. P. Roberts \\ University Department of Surgery, The Welsh National School of Medicine, \\ Heath Park, Cardiff CF4 4 XN, U.K.
}

The fetus, by virtue of its paternal complement of genes, carries histocompatibility antigens foreign to the mother and should be subject to immunological rejection. That this does not occur has been attributed to a physiological barrier between mother and fetus (Billingham, 1964), to the presence of blocking antibodies (Hellstrom \& Hellstrom, 1973; Taylor \& Hancock, 1975) and to inhibition of lymphocyte stimulation by placental hormones (Adcock et al., 1973; Contractor \& Davies, 1973; Beling \& Weksler, 1974; Han, 1974). Of the latter, HCG has received most attention and the inhibitory effects demonstrated have been largely confined to human lymphocytes. Hormones similar to HCG have not been detected in other species (Deanesly, 1966). Of particular interest is the cow in which the embryo lies free in the uterine lumen for a relatively long time and implantation does not take place until considerable growth and development of the embryo has occurred (Melton, Berry \& Butler, 1951). The present investigation of the factors which protect the bovine embryo during this early developmental stage involved the use of lymphocyte stimulation by phytohaemagglutinin (PHA) as a measure of the cell-mediated immune response.

Uterine proteins were obtained by concentration of uterine washings and details of their collection and protein content have been reported elsewhere (Roberts \& Parker, 1974). Solutions of bovine uterine proteins and serum diluted with saline were sterilized using a Sartorius filter $(0 \cdot 45 \mu \mathrm{m}$ V.A. Howe, U.K.). Lymphocyte suspensions, prepared from bovine mediastinal lymph nodes (Ferber, Resch, Wallach \& Imm, 1972), were washed twice with saline, once with Dulbecco's medium containing $15 \%$ fetal calf serum and $14 \mathrm{~mm}$-Hepes buffer and re-suspended at a concentration of $1.67 \times$ $10^{6} \mathrm{cells} / \mathrm{ml}$ in the latter medium. Measurement of lymphocyte stimulation by PHA (Wellcome Laboratories, U.K.) was carried out by a microculture technique (Whitehead, Bolton, Newcombe, James \& Hughes, 1975) with an incubation of $16 \mathrm{~h}$ between addition of tritiated thymidine and harvesting.

The dose-response curve of the inhibition of PHA-induced lymphocyte stimulation by uterine proteins from an 18-day pregnant cow is shown in Text-fig. 1. Sera from a cow 18 days pregnant and pooled sera from a group of cows 7-31 days pregnant did not inhibit PHA-induced lymphocyte stimulation when used at concentrations as high as $3 \mathrm{mg} / \mathrm{ml}$. The protein values shown in Text-fig. 1 were measured by the method of Lowry, Rosebrough, Farr \& Randall (1951) and refer to the total protein in the uterine samples. However, it has been shown previously (Roberts \& Parker, 1974) that most of the proteins in uterine washings are serum proteins and the non-serum components account for less than $0.2 \%$ of the total protein. Thus the component(s) inhibiting lymphocyte stimulation are active at very low concentrations, probably lower than the concentration at which HCG was reported (Contractor \& Davies, 1973) to inhibit transformation of human lymphocytes.

Although the proteins concentrated from uterine washings are referred to as uterine proteins the component(s) responsible for inhibition of lymphocyte stimulation may be derived from the embryo. It is clear from the results in Table 1 that the inhibitory activity of the uterine proteins increases markedly between Days 13 and 18 of pregnancy and that uterine proteins from cows more than 18 days pregnant completely abrogate the effect of PHA. This increased inhibitory activity correlates with a change in the electrophoretic patterns of uterine proteins at this stage of pregnancy (Roberts \& Parker, 1974). Furthermore, it is during this period that a rapid elongation and expansion of the embryo occurs, leading to close apposition of the trophoblast and endometrium. 


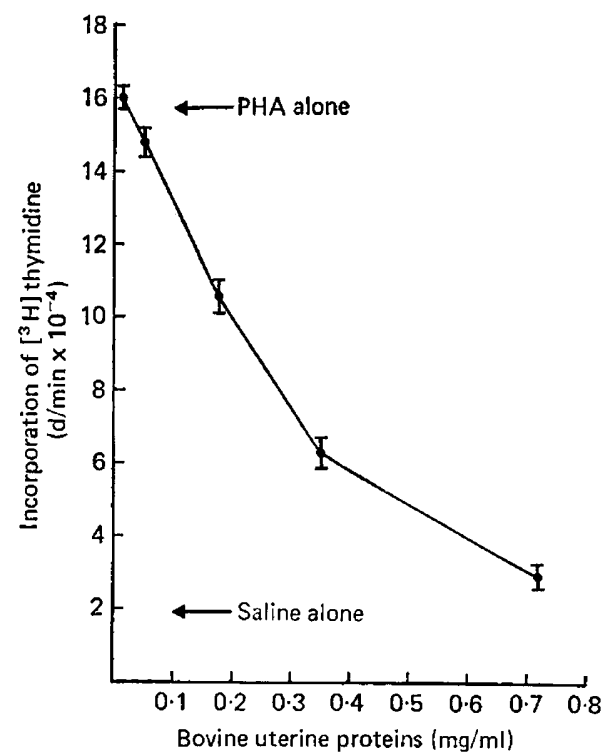

Text-fig. 1. Dose-dependent inhibition of PHA-induced incorporation of $\left[{ }^{3} \mathrm{H}\right]$ thymidine into bovine lymphocytes by increasing amounts of bovine uterine proteins from an 18-day pregnant cow. PHA at a final concentration of $4 \mu \mathrm{g} / \mathrm{ml}$ was used for stimulation. The $\left[{ }^{3} \mathrm{H}\right]$ thymidine incorporated by lymphocytes in the presence of PHA alone and saline alone are shown by the arrows. The vertical lines represent the S.E.M. of 3 estimations at each point.

Table 1. Inhibition of PHA-induced stimulation of bovine lymphocytes (at a final concentration of $4 \mu \mathrm{g}$ PHA $/ \mathrm{ml})$ by uterine proteins $(400 \mu \mathrm{g} / \mathrm{ml}$ final concentration) at different stages of the oestrous cycle and pregnancy

\begin{tabular}{lcc}
\hline & $\begin{array}{c}\text { Day of oestrous cycle } \\
\text { or pregnancy }\end{array}$ & $\begin{array}{c}{\left[{ }^{3} \mathrm{H}\right] \mathrm{Thymidine} \text { incorporation }} \\
(\mathrm{d} / \mathrm{min})\end{array}$ \\
\hline Saline alone & - & $19,116 \pm 607$ \\
PHA alone & - & $156,876 \pm 4,662$ \\
Unmated & 14 & $150,019 \pm 5,211$ \\
Unmated & 16 & $145,874 \pm 7,025$ \\
Pregnant & 10 & $143,127 \pm 8,256$ \\
Pregnant & 13 & $148,629 \pm 4,899$ \\
Pregnant & 15 & $125,088 \pm 3,978$ \\
Pregnant & 17 & $50,868 \pm 3,423$ \\
Pregnant & 18 & $19,805 \pm 2,932$ \\
Pregnant & 20 & $18,378 \pm 2,158$ \\
\hline
\end{tabular}

Values are mean \pm S.E.M. for triplicate assays of samples from individual cows.

The mechanism by which uterine proteins inhibit PHA-induced lymphocyte stimulation is unknown but some possible mechanisms can be eliminated. It has been reported (Caldwell, Stites \& Fudenberg, 1975) that the inhibition of human lymphoctye stimulation by HCG is the result of an impurity in the HCG preparations binding the PHA and making it unavailable for lymphocyte transformation. Such a mechanism for the inhibition by bovine uterine proteins is unlikely because microscopic examination of the lymphocytes after treatment with PHA and uterine proteins revealed similar aggregations of lymphocytes to those in control samples with PHA alone. Uterine proteins inhibited lymphocyte stimulation when they were added $2 \mathrm{~h}$ after the PHA, an interval long enough for the PHA to have become attached to the lymphocytes (Ling, 1971). Furthermore, the inhibition was not markedly altered when 5-fold changes were made in the PHA concentration used for stimulation. The possibility that uterine proteins could act as non-specific metabolic poisons can also be 
eliminated since lymphocytes incubated in the presence of bovine uterine proteins but without PHA incorporated similar amounts of radioactivity to lymphocytes incubated with saline. Trypan blue exclusion tests revealed that the numbers of viable lymphocytes were similar in samples incubated for $72 \mathrm{~h}$ with uterine proteins and in those incubated in saline. The inhibition of lymphocyte stimulation was species-specific and bovine uterine proteins from 18-day pregnant cows did not inhibit PHAinduced stimulation of human or ovine lymphocytes.

The inhibitory effects of bovine uterine proteins on in-vitro lymphocyte stimulation demonstrated here may be of physiological importance in protecting the embryo from rejection, and a defect in production of the active component(s) could therefore be a major factor contributing to early embryonic loss.

This work was supported by the Cancer Research Campaign.

\section{References}

Adcock, E.W., Teasdale, F., August, C.S., Cox, S., Meschia, G., Battaglia, F.C. \& Naughton, M.A. (1973) Human chorionic gonadotropin: its possible role in maternal lymphocyte suppression. Science, N.Y. 181, 845-847.

Beling, C.G. \& Weksler, M.E. (1974) Suppression of mixed lymphocyte reactivity by human chorionic gonadotrophin. Clin. exp. Immun. 18, 529-535.

Brllingham, R.E. (1964) Transplantation immunity and the maternal-fetal relation. New Eng. J. Med. 270, 667-672.

Caldwell, J.L., Stites, D.P. \& FudenberG, H.H. (1975) Human chorionic gonadotropin: effects of crude and purified preparations on lymphocyte responses to phytohemagglutinin and allogeneic stimulation. J. Immun. 115, 1249-1253.

Contractor, S.F. \& DAvies, H. (1973) Effect of human chorionic somatomammotrophin and human chorionic gonadotrophin 'on phytohaemagglutinin-induced lymphocyte transformation. Nature, New Biol. 243, 284-286.

Deanesly, R. (1966) The endocrinology of pregnancy and foetal life. In Marshall's Physiology of Reproduction Vol. 3, pp. 891-1063. Ed. A. S. Parkes. Longman's Green, London.

Ferber, E., Resch, K., WAllach, D.F.H. \& IMM, W. (1972) Isolation and characterization of lymphocyte plasma membranes. Biochim. biophys. Acta 266, 494-504.
HAN, T. (1974) Inhibitory effect of human chorionic gonadotrophin on lymphocyte blastogenic response to mitogen, antigen and allogeneic cells. Clin. exp. Immun. 18, 529-535.

Hellstrom, K.E. \& Hellstrom, I.A. (1973) Lymphocyte-mediated cytotoxicity and blocking serum activity to tumor antigens. Adv. Immun. 18, 209277.

LING, N.R. (1971) Lymphocyte Stimulation. NorthHolland Publishing Co., Amsterdam.

Lowry, O.H., Rosebrough, N.J., Farr, A.L. \& RANDALL, R.J. (1951) Protein measurement with the Folin phenol reagent. J. biol. Chem. 193, 265275.

Melton, A.A., Berry, R.O. \& Butler, O.D. (1951) The interval between the time of ovulation and attachment of the bovine embryo. J. Anim. Sci. 10, 9931005.

RoberTs, G.P. \& Parker, J.M. (1974) Macromolecular components of the luminal fluid from the bovine uterus. J. Reprod. Fert. 40, 291-303.

TAYLOR, P.V. \& HANCOCK, K.W. (1975) Antigenicity of trophoblast and possible antigen-masking effects during pregnancy. Immunology 28, 973-982.

Whitehead, R.H. Bolton, P.M., Newcombe, R.G., JAMES, S.L. \& Hughes, L.E. (1975) Lymphocyte response to PHA in breast cancer: correlation of predicted prognosis to response to different PHA concentrations. Clin. Oncol. 1, 191-200.

Received 15 November 1976 